\title{
Varying Protein and Starch in the Diet of Dairy Cows. II. Effects on Performance and Nitrogen Utilization for Milk Production
}

\author{
I. R. Ipharraguerre and J. H. Clark \\ Department of Animal Sciences, University of Illinois, Urbana 61801
}

\begin{abstract}
The main objective of this experiment was to examine the effects of the percentage and source of crude protein (CP) and the amount of starch in the diet of dairy cows on the lactational performance and use of $\mathrm{N}$ for milk production. Sixty multiparous Holstein cows were used in a $210-d$ lactational trial with a completely randomized design with a $2 \times 3$ factorial arrangement of treatments. Two sources of CP [solvent-extracted soybean meal (SBM) and a mixture of SBM and a blend of animalmarine protein supplements plus ruminally protected Met $(\mathrm{AMB})]$ and 3 levels of dietary CP $($ means $=14.8$, 16.8 , and $18.7 \%$ ) were combined into 6 treatments. On a dry matter (DM) basis, diets contained $25.0 \%$ corn silage, $20.0 \%$ alfalfa silage, $10.0 \%$ cottonseed, 26.7 to $37.0 \%$ corn grain, and 4.8 to $13.5 \%$ protein supplement, plus minerals and vitamins. Across the $210 \mathrm{~d}$ of lactation, the productive response of dairy cows to the source of supplemental $\mathrm{CP}$ depended on the concentration of $\mathrm{CP}$ in the diet. At $18.7 \% \mathrm{CP}$, cows fed SBM consumed more DM and produced more milk, 3.5\% fat-corrected milk, fat, and true protein, but had lower efficiency of feed use and body condition score than cows fed AMB. At 16.8\% $\mathrm{CP}$, cows fed AMB produced more 3.5\% fat-corrected milk, fat, and true protein than cows fed SBM. At $14.8 \%$ $\mathrm{CP}$, cows fed SBM consumed more DM but produced less true protein and had lower feed efficiency than cows fed AMB. Across CP sources, cows fed $14.8 \%$ CP produced less fat-corrected milk and true protein than cows fed 16.8 and $18.7 \%$ CP. Across CP percentages, cows fed AMB produced more fat-corrected milk per kilogram of DM consumed than cows fed SBM. Despite these interactions, improvements in the gross efficiency of $\mathrm{N}$ use for milk production were achieved through reductions in the intake of $\mathrm{N}$ independently of the source of $\mathrm{CP}$. Data suggest that the intake of $\mathrm{N}$ by high-producing dairy cows that consume sufficient energy and other nutrients to meet their requirements can be decreased to about
\end{abstract}

Received October 22, 2004.

Accepted March 25, 2005.

Corresponding author: Ignacio R. Ipharraguerre; e-mail: ipharrag @uiuc.edu.
600 to $650 \mathrm{~g}$ daily if the source of RDP and RUP are properly matched with the source and amount of carbohydrate in the diet.

(Key words: dairy cow, milk production, gross efficiency of nitrogen utilization, protein)

Abbreviation key: AMB = blend of animal-marine protein supplements plus ruminally protected Met, EAA = essential amino acids, $\mathbf{H C P}=$ high $\mathrm{CP}, \mathbf{L C P}=$ low $\mathbf{C P}$, $\mathbf{M C P}=$ medium CP, $\mathbf{M E}=$ metabolizable energy, $\mathbf{M P}=$ metabolizable protein, $\mathbf{S B M}=$ solvent-extracted soybean meal.

\section{INTRODUCTION}

Mass nitrogen balance studies showed that on typical dairy farms only 12 to $36 \%$ of the $\mathrm{N}$ input is retained in salable products, whereas up to about 70\% is lost mainly through volatilization and leaching into the off-farm environment (Klausner, 1993; Castillo et al., 2000; Spears et al., 2003). This inefficient use of $\mathrm{N}$ for productive purposes may be exacerbated by the current trend among dairy producers to feed more CP than is apparently required by lactating dairy cows (Castillo et al., 2000; Jonker et al., 2002). Overfeeding $\mathrm{N}$ to dairy cows may have detrimental effects not only on the productive performance but also on the efficiency of nutrient use for milk production, reproductive performance, economic returns, environment, and public perception of dairy farming (NRC, 2001; CAST, 2002). It is widely recognized, however, that advancing our knowledge about the protein requirements of today's high-producing dairy cow is a prerequisite for optimizing cow productivity and minimizing nutrient excretion into the environment (NRC, 2001; CAST, 2002).

Results from various research and modeling approaches suggest that improving the efficiency of $\mathrm{N}$ use by dairy cows, which in most production schemes rarely exceeds 25 to $30 \%$, is the most promising way to decrease $\mathrm{N}$ losses from dairy farms with minimal detrimental effects, if any, on their productivity and profitability (Kohn et al., 1997; Rotz et al., 1999; St-Pierre and Thraen, 1999). Reducing the output of $\mathrm{N}$ in urine provides the greatest opportunity for achieving that goal (Hvelplund and Madsen, 1996). This is because most of 
the $\mathrm{N}$ present in urine arises from inefficient $\mathrm{N}$ transactions in the rumen and tissues of cows that may be amenable to manipulation (Lobley, 2002). In recent years, several researchers reported that decreasing the amount of dietary $\mathrm{CP}$ while correcting for predicted shortages of limiting AA for milk production by including RUP supplements (Castillo et al., 2001; Noftsger and StPierre, 2003) and (or) rumen-protected AA (Dinn et al., 1998; Kröber et al., 2000b; Noftsger and St-Pierre, 2003) in the diet can reduce excretion of $\mathrm{N}$ in urine and sustain production of milk and milk protein. However, crossover designs with short experimental periods were used in most studies (Dinn et al., 1998; Kröber et al., 2000b; Noftsger and St-Pierre, 2003) and negative controls were not included in others (Dinn et al., 1998; Noftsger and StPierre, 2003). In addition, in most cases the CP content of the diet was reduced by replacing high-protein supplements with sources of structural or nonstructural carbohydrates. Therefore, it is uncertain 1) whether those desirable effects are attainable during long feeding periods; 2) whether the effects of reducing dietary CP and feeding RUP supplements and (or) rumen-protected AA are additive or mutually independent; and 3) whether the effects of reducing dietary $\mathrm{CP}$ are related to alterations in the interrelationship between protein and carbohydrates in the digestive tract of dairy cows.

Two experiments were conducted concurrently to test the broad hypothesis that the CP content of the diet can be decreased to improve the efficiency of $\mathrm{N}$ use for milk production without affecting negatively the supply of metabolizable protein (MP) and the lactational performance of dairy cows if the source and amount of CP are properly matched with the source and amount of carbohydrate in the diet. The objectives of the experiment reported here were 1) to examine the effects of the amount and source of $\mathrm{CP}$ and the amount of starch in the diet of dairy cows on the lactational performance and use of $\mathrm{N}$ for milk production, and 2) to relate differences in cow productivity and conversion of feed $\mathrm{N}$ to milk $\mathrm{N}$ to alterations in ruminal fermentation, intestinal supply of nutrients, and use of nutrients by dairy cows determined in the companion experiment (Ipharraguerre et al., 2005).

\section{MATERIALS AND METHODS}

\section{Experimental Design and Treatments}

A 210-d lactation trial using a completely randomized design with a $2 \times 3$ factorial arrangement of treatments was conducted according to procedures approved by the University of Illinois Laboratory Animal Care Advisory Committee.

Two sources of protein of different ruminal degradability and 3 concentrations (percentage) of dietary $\mathrm{CP}$ were combined into 6 dietary treatments: 1) low CP (LCP), solvent-extracted soybean meal (SBM); 2) LCP, blend of animal-marine protein supplements (i.e., meals of blood, porcine meat and bone, menhaden fish, and hydrolyzed feather) plus ruminally protected Met (AMB); 3) medium CP (MCP), SBM; 4) MCP, AMB; 5) high CP (HCP), SBM; and 6) HCP, AMB. Diets were formulated to contain $14 \%(\mathrm{LCP}), 16 \%(\mathrm{MCP})$, or $18 \% \mathrm{CP}(\mathrm{HCP})$ by replacing an increasing proportion of corn with protein supplements as the CP content of the diet increased (Table 1). The AMB supplement (ProLak; H. J. Baker \& Bros., Inc., Westport, CT) partially replaced SBM in the concentrate mixtures with the aim of enhancing the content of RUP in the diets (Table 1). Our ultimate goal was to improve quantitatively and qualitatively the supply of MP at each concentration of dietary CP through increased input of digestible RUP with an AA composition balanced to complement microbial protein. The remaining dietary ingredients were supplied from the same source and in the amounts needed to meet the NRC (2001) nutrient requirements (Table 1).

\section{Animals and Management}

Immediately after calving, 60 multiparous Holstein cows were housed in individual tie stalls equipped with water bowls and bedded with sawdust. During the first $14 \mathrm{~d}$ postcalving, all cows were fed the same pretreatment diet that was prepared by mixing equal quantities (50:50, wt/wt) of diets MCP/SBM and MCP/ABM. In addition, cows were offered $2 \mathrm{~kg}$ of alfalfa hay daily for the first $7 \mathrm{~d}$ postcalving. Measurements taken during $\mathrm{d} 7$ to 14 of the pretreatment period were used for covariance adjustment of response parameters. On d 15 postcalving, cows were randomly assigned to 1 of the 6 dietary treatments and fed their assigned diet until d 210 of lactation. Cows were fed diets as TMR twice daily at 1000 and $1700 \mathrm{~h}$ in amounts to ensure $10 \%$ orts. The TMR were adjusted weekly to reflect changes in DM content of forages and concentrate mixtures by drying the forages and concentrates overnight at $105^{\circ} \mathrm{C}$. During the $210 \mathrm{~d}$, cows were milked twice daily at 0300 and $1500 \mathrm{~h}$ and were let outside in a dry lot to exercise from 0700 to $0900 \mathrm{~h}$ daily. The study was conducted over $2 \mathrm{yr}$, and 30 cows were assigned to treatment each year. Two cows, one fed the LCP/SBM treatment and a second fed the MCP/ SBM treatment, were removed from the experiment because of retained placenta followed by metritis and low milk production.

\section{Sampling, Analyses, and Calculations}

From calving until d 210, feed offered was recorded daily. Orts were weighed daily and were scored on a 4- 
Table 1. Ingredient and chemical composition of the experimental $\operatorname{diets}^{1}$ (DM basis).

\begin{tabular}{|c|c|c|c|c|c|c|}
\hline \multirow[b]{2}{*}{ Item } & \multicolumn{2}{|c|}{ LCP } & \multicolumn{2}{|c|}{ MCP } & \multicolumn{2}{|c|}{$\mathrm{HCP}$} \\
\hline & SBM & $\mathrm{AMB}$ & SBM & AMB & SBM & AMB \\
\hline \multicolumn{7}{|l|}{ Ingredient } \\
\hline Alfalfa silage, $\%$ & 20.00 & 20.00 & 20.00 & 20.00 & 20.00 & 20.00 \\
\hline Corn silage, \% & 25.00 & 25.00 & 25.00 & 25.00 & 25.00 & 25.00 \\
\hline Cottonseed (w/lint), \% & 10.00 & 10.00 & 10.00 & 10.00 & 10.00 & 10.00 \\
\hline Ground shelled corn, \% & 36.42 & 37.01 & 30.80 & 34.01 & 26.65 & 30.67 \\
\hline Soybean meal (49\% CP), \% & 4.75 & 2.33 & 9.13 & 4.48 & 13.50 & 6.62 \\
\hline Animal-marine protein blend, ${ }^{2} \%$ & $\ldots$ & 1.73 & $\ldots$ & 3.32 & $\ldots$ & 4.90 \\
\hline Soyhulls, \% & $\ldots$ & $\ldots$ & 1.50 & $\ldots$ & 1.50 & $\ldots$ \\
\hline Inert fat, ${ }^{3} \%$ & $\ldots$ & 0.36 & $\ldots$ & $\ldots$ & $\ldots$ & $\ldots$ \\
\hline Sodium bicarbonate, $\%$ & 1.00 & 1.00 & 1.00 & 1.00 & 1.00 & 1.00 \\
\hline Sodium chloride, $\%$ & 0.25 & 0.25 & 0.25 & 0.25 & 0.25 & 0.25 \\
\hline Mineral and vitamin $\operatorname{mix},{ }^{4} \%$ & 0.25 & 0.25 & 0.25 & 0.25 & 0.25 & 0.25 \\
\hline Dicalcium phosphate, \% & 0.62 & 0.52 & 0.54 & 0.32 & 0.45 & 0.12 \\
\hline Limestone, \% & 1.08 & 0.93 & 1.07 & 0.95 & 1.10 & 0.94 \\
\hline Magnesium oxide, \% & 0.17 & 0.18 & 0.15 & 0.17 & 0.14 & 0.17 \\
\hline Sodium sulfate, $\%$ & 0.46 & 0.44 & 0.31 & 0.25 & 0.16 & 0.08 \\
\hline \multicolumn{7}{|l|}{ Chemical composition } \\
\hline $\mathrm{DM}, \%$ & 63.3 & 63.5 & 63.3 & 63.7 & 63.4 & 63.3 \\
\hline $\mathrm{CP}, \%$ & 14.8 & 14.9 & 16.6 & 17.0 & 18.5 & 19.0 \\
\hline Soluble CP, \% of CP & 36.4 & 36.2 & 36.0 & 35.6 & 36.1 & 34.9 \\
\hline RUP, ${ }^{5} \%$ & 5.0 & 5.4 & 5.8 & 6.5 & 6.6 & 7.7 \\
\hline $\mathrm{RUP}, 5 \%$ of CP & 33.8 & 36.2 & 34.9 & 38.2 & 35.7 & 40.5 \\
\hline $\mathrm{RDP}, 5 \%$ & 9.8 & 9.5 & 10.8 & 10.5 & 11.9 & 11.3 \\
\hline $\mathrm{NDF}, \%$ & 28.0 & 28.2 & 28.9 & 28.3 & 29.2 & 28.6 \\
\hline $\mathrm{ADF}, \%$ & 18.6 & 18.7 & 19.3 & 18.9 & 19.7 & 19.1 \\
\hline $\mathrm{NFC},{ }^{5} \%$ & 45.3 & 45.0 & 42.6 & 43.5 & 40.8 & 41.6 \\
\hline Starch, ${ }^{6} \%$ & 32.8 & 33.0 & 29.6 & 30.5 & 27.0 & 29.4 \\
\hline $\mathrm{NE}_{\mathrm{L}}, \mathrm{Mcal} / \mathrm{kg}$ of $\mathrm{DM}^{5}$ & 1.53 & 1.51 & 1.53 & 1.52 & 1.54 & 1.53 \\
\hline $\mathrm{Ca}, \%$ & 1.02 & 1.01 & 0.99 & 1.03 & 1.01 & 1.04 \\
\hline $\mathrm{P}, \%$ & 0.53 & 0.52 & 0.52 & 0.52 & 0.52 & 0.52 \\
\hline $\mathrm{Mg}, \%$ & 0.32 & 0.32 & 0.31 & 0.32 & 0.32 & 0.32 \\
\hline $\mathrm{K}, \%$ & 1.12 & 1.07 & 1.21 & 1.13 & 1.30 & 1.17 \\
\hline
\end{tabular}

${ }^{1} \mathrm{AMB}=$ Animal-marine protein blend, $\mathrm{HCP}=$ high $\mathrm{CP}$ diet, $\mathrm{LCP}=$ low $\mathrm{CP}$ diet, $\mathrm{MCP}=$ medium $\mathrm{CP}$ diet, SBM = solvent-extracted soybean meal.

${ }^{2}$ ProLak (H. J. Baker \& Bros., Inc., Westport, CT).

${ }^{3}$ Megalac (Church \& Dwight, Co., Inc., Princeton, NJ).

${ }^{4}$ Contained $5.0 \% \mathrm{Mg}, 7.5 \% \mathrm{~K}, 10.0 \% \mathrm{~S}, 3.0 \% \mathrm{Zn}, 3.0 \% \mathrm{Mn}, 2.0 \% \mathrm{Fe}, 0.5 \% \mathrm{Cu}, 0.025 \% \mathrm{I}, 0.015 \% \mathrm{Se}, 0.004 \%$ Co, $2200 \mathrm{IU}$ of vitamin $\mathrm{A} / \mathrm{g}, 660 \mathrm{IU}$ of vitamin $\mathrm{D}_{3} / \mathrm{g}$, and $8 \mathrm{IU}$ of vitamin $\mathrm{E} / \mathrm{g}$.

${ }^{5}$ Calculated using tabulated values from NRC (2001) and assuming an intake of 4 times maintenance. It was also assumed that ProLak contains $70 \%$ of the CP as RUP and 1.50 Mcal of $\mathrm{NE}_{\mathrm{L}}$ per kg of DM.

${ }^{6}$ Data from Ipharraguerre et al. (2005) for the same diets.

point scale, where $1=$ dry and $4=$ wet. On $\mathrm{d} 7$ and 14 postcalving and, afterward, during the last day of each 4wk period, samples of orts were collected and DM content was determined by drying samples from individual cows at $105^{\circ} \mathrm{C}$ for $24 \mathrm{~h}$. For each cow, these determinations were used to assign a percentage of DM to each bunk score. Dry matter intake was calculated from the amount of feed offered and its DM content, the amount of orts, and the DM percentage that was assigned to each bunk score for each cow. Samples of forages, concentrates, and TMR were collected once a week and divided into 2 representative subsamples. One subsample of feed was used to determine DM as described for orts and the other subsample was stored frozen at $-20^{\circ} \mathrm{C}$ for later analyses. At the end of each 4-wk period, feed subsamples from the weekly collections were thawed, combined on an equal weight basis, and sent to the Dairy One, Inc., Forage Testing Laboratory (Ithaca, NY) where they were analyzed for Kjeldahl N (AOAC, 1990), ADF (Van Soest et al., 1991), NDF with heat-stable $\alpha$-amylase and sodium sulfite (Van Soest et al., 1991), and Ca, P, Mg, and K by inductively coupled plasma spectrometry.

Milk production was recorded automatically at each milking throughout the experiment. Milk samples were collected at each milking on d 11 to 13 and weekly from 2 consecutive milkings for the duration of the experiment. Individual milk samples were preserved with 2-bromo2-nitropropane-1,3-diol and stored at $4^{\circ} \mathrm{C}$ until shipment to Dairy One Cooperative, Inc., Milk Check Laboratory (Ithaca, NY) for analyses of fat, CP, true protein, lactose, 
total solids, MUN, and somatic cells by infrared procedures (AOAC, 1990; Foss 4000; Foss North America, Eden Prairie, MN). Daily milk composition was estimated as an average of the a.m. and p.m. milk samples corrected by the proportion of daily production at that milking.

Over the course of the study, BW were recorded weekly at $0700 \mathrm{~h}$ starting on $\mathrm{d} 1$ postcalving. Measurement of BW was conducted after the morning milking and before the morning feeding. Body condition scores were determined by the same 2 individuals on $\mathrm{d} 7$ postcalving and thereafter every $28 \mathrm{~d}$ until the end of the trial using a 5.00-point scale in quarter-point increments, where $1=$ thin and 5 = fat (Wildman et al., 1982).

The intake of $\mathrm{N}$ was estimated using the calculated DMI and the determined N content of the TMR. Secretion of $\mathrm{N}$ in milk $(\mathrm{g} / \mathrm{d})$ was calculated by multiplying daily milk production by the percentage of milk CP divided by 6.38. The concentration of MUN and BW were used to estimate excretion of $\mathrm{N}(\mathrm{g} / \mathrm{d})$ in urine according to the equation developed by Kauffman and St-Pierre (2001). The difference between $\mathrm{N}$ intake and $\mathrm{N}$ output in milk plus urine was assumed to represent excretion of $\mathrm{N}$ in feces.

\section{Statistical Analyses}

Before analysis, data for DMI, milk production, and milk composition were reduced to weekly means for each cow. These data were analyzed from d 15 to 112 and from d 15 to 210 to test whether animal responses to treatments were altered by stage of lactation. Likewise, data from low-producing $(\mathrm{n}=29)$ and high-producing $(\mathrm{n}=29)$ cows were stratified based on milk yield $(<$ or $\geq$ $40 \mathrm{~kg} / \mathrm{d}$ ) and analyzed from d 15 to 112 to assess whether animal responses to treatments were dependent on cow productivity. In both cases, data were subjected to covariance adjustment using data from $\mathrm{d} 8$ to 14 of the pretreatment period and analyzed as repeated measures in time using the MIXED procedure of SAS (Littell et al., 1996). The mixed model contained the effects of year, covariate, treatment (percentage, source, and percentage $\times$ source of CP), cow within year and treatment, time (week of lactation), and all possible interactions among year, treatment, and time. Year and cow within year and treatment were treated as random factors. If the variance estimate for the random effect of year was zero or close to zero, then year was dropped from the model. For each model tested, the smallest value for the Akaike's information criterion was used to identify the most appropriate covariance structure (Littell et al., 1996).

The maximum loss of BW and BCS were estimated by subtracting the lowest BW and BCS for each cow during the experimental period from the BW (d 14) and
Table 2. Chemical composition of feed ingredients (DM basis).

\begin{tabular}{llcc}
\hline & \multicolumn{2}{c}{ Silages } & \\
\cline { 2 - 3 } Item & Alfalfa & Corn & Cottonseed \\
\hline $\mathrm{DM}, \%$ & 55.7 & 41.6 & 91.3 \\
$\mathrm{NDF}, \%$ & 47.6 & 41.0 & 43.8 \\
ADF, \% & 37.3 & 25.3 & 33.1 \\
NFC, \% & 21.1 & 43.2 & 5.1 \\
CP, \% & 20.4 & 7.8 & 29.8 \\
Soluble CP, \% of CP & 51.4 & 57.0 & 26.9 \\
Ca, \% & 1.36 & 0.25 & 0.17 \\
P, \% & 0.36 & 0.29 & 0.92 \\
Mg, \% & 0.25 & 0.16 & 0.45 \\
K, \% & 2.48 & 1.10 & 1.16 \\
\hline
\end{tabular}

BCS (d 7) measured during the pretreatment period, respectively. These data were analyzed as a completely randomized design using the MIXED procedure of SAS (SAS Institute, 2000). In this case, the mixed model contained the effects of year (random), treatment (percentage, source, and percentage $\times$ source of CP; fixed), cow within year and treatment (random), and interactions of year by treatment. The analysis was conducted according to criteria described above.

Data for energy balance and $\mathrm{N}$ use were reduced to weekly means for each cow and analyzed from d 15 to 210 using the aforementioned mixed model and repeated measures approach, but without covariance adjustment. In addition, data for $\mathrm{N}$ use were also analyzed from $\mathrm{d}$ 42 to 49 , d 112 to 119 , and d 196 to 203 to evaluate the influence of the stage of lactation on the impact of treatments on the gross conversion of feed $\mathrm{N}$ into milk $\mathrm{N}$, as described for the maximum loss of BW and BCS.

Least square means were separated into significant main effects by the PDIFF option of SAS (SAS Institute, 2000). Differences among treatments were considered to be significant when $P<0.05$, whereas when $P>0.05$ but $<0.10$ differences were considered to indicate a trend toward a significant effect.

\section{RESULTS AND DISCUSSION}

\section{Chemical Composition of Diets and Feed Ingredients}

The percentage of CP averaged 14.8, 16.8, and 18.7 for the LCP, MCP, and HCP diets, respectively (Table 1). As indicated earlier, diets were formulated to contain 0.8 percentage units less CP than these amounts. Probably, this discrepancy occurred because cottonseed had on average $22.5 \%$ more CP (Table 2) than the sample of cottonseed analyzed for formulating the diets (i.e., 29.8 vs. $23.1 \%$ ). As intended, however, the difference between concentrations of dietary $\mathrm{CP}$ (i.e., LCP vs. MCP and MCP vs. HCP) was on average 2 percentage units with minimal variation between sources of supplemental CP. 
Table 3. Least square means for performance of cows fed diets containing different percentages and sources of CP. ${ }^{1}$

\begin{tabular}{|c|c|c|c|c|c|c|c|c|c|c|}
\hline \multirow[b]{3}{*}{ Item } & \multirow{2}{*}{\multicolumn{2}{|c|}{ LCP }} & \multirow{2}{*}{\multicolumn{2}{|c|}{ MCP }} & \multirow{2}{*}{\multicolumn{2}{|c|}{ HCP }} & \multirow[b]{3}{*}{ SEM } & \multicolumn{3}{|c|}{$\operatorname{Effect}^{2}(P>\mathrm{F})$} \\
\hline & & & & & & & & & & $\mathrm{CP} \% \times$ \\
\hline & SBM & $\mathrm{AMB}$ & SBM & $\mathrm{AMB}$ & SBM & $\mathrm{AMB}$ & & $\mathrm{CP} \%$ & Source & source \\
\hline \multicolumn{11}{|l|}{ DMI, kg/d } \\
\hline d 15 to 112 & 24.7 & 23.2 & 24.6 & 25.6 & 26.3 & 24.2 & 0.56 & 0.04 & 0.04 & 0.01 \\
\hline d 15 to 210 & 24.5 & 23.9 & 24.7 & 25.1 & 26.0 & 23.5 & 0.48 & $\mathrm{NS}^{3}$ & NS & 0.002 \\
\hline \multicolumn{11}{|l|}{ DMI, \% of BW } \\
\hline d 15 to 112 & 3.92 & 3.65 & 3.81 & 4.00 & 4.09 & 3.70 & 0.09 & NS & 0.02 & 0.002 \\
\hline d 15 to 210 & 3.85 & 3.65 & 3.75 & 3.87 & 4.05 & 3.54 & 0.07 & NS & 0.001 & 0.0001 \\
\hline \multicolumn{11}{|l|}{ Milk, kg/d } \\
\hline d 15 to 112 & $39.4^{\mathrm{b}}$ & $40.0^{\mathrm{b}}$ & $41.6^{\mathrm{a}}$ & $43.1^{\mathrm{a}}$ & $43.3^{\mathrm{a}}$ & $42.8^{\mathrm{a}}$ & 1.05 & 0.005 & NS & NS \\
\hline d 15 to 210 & 36.3 & 37.3 & 37.3 & 38.7 & 39.4 & 37.8 & 1.31 & NS & NS & NS \\
\hline \multicolumn{11}{|l|}{$3.5 \% \mathrm{FCM}^{4}{ }^{4} \mathrm{~kg} / \mathrm{d}$} \\
\hline d 15 to 112 & 39.3 & 38.1 & 38.9 & 42.2 & 42.4 & 40.8 & 0.89 & 0.04 & NS & 0.06 \\
\hline d 15 to 210 & 35.8 & 35.8 & 35.2 & 38.1 & 39.0 & 36.8 & 0.81 & 0.03 & NS & 0.005 \\
\hline \multicolumn{11}{|l|}{ FCM/DMI } \\
\hline d 15 to 112 & 1.60 & 1.67 & 1.62 & 1.66 & 1.66 & 1.72 & 0.04 & NS & 0.08 & NS \\
\hline d 15 to 210 & 1.46 & 1.52 & 1.46 & 1.52 & 1.52 & 1.58 & 0.04 & 0.07 & 0.04 & NS \\
\hline
\end{tabular}

${ }^{a, b}$ Means within a row with different superscripts differ significantly for the main effect of CP percentage. Pairwise comparisons were calculated using the appropriate standard error.

${ }^{1} \mathrm{AMB}=$ Animal-marine protein blend, $\mathrm{HCP}=$ high $\mathrm{CP}$ diet, $\mathrm{LCP}=$ low $\mathrm{CP}$ diet, $\mathrm{MCP}=$ medium $\mathrm{CP}$ diet, $\mathrm{SBM}=$ solvent-extracted soybean meal.

${ }^{2} \mathrm{CP} \%=$ Percentage of $\mathrm{CP}$, Source $=$ source of $\mathrm{CP}, \mathrm{CP} \% \times$ source $=$ interaction between percentage and source of $\mathrm{CP}$. The 2-way interactions and 3-way interaction between factors and week of lactation were not significant $(P>0.10)$.

${ }^{3}$ Nonsignificant $(P>0.10)$

${ }^{4} 3.5 \% \mathrm{FCM}=0.4324(\mathrm{~kg}$ of milk $)+16.216(\mathrm{~kg}$ of fat $)$.

At all concentrations of dietary $\mathrm{CP}$, the replacement of SBM with AMB increased the RUP content of the diet (Table 1) either expressed as percentage of dietary DM $(+0.4,0.7$, and 1.1 percentage units) or as proportion of dietary $\mathrm{CP}(+2.4,3.3$, and 4.8 percentage units). Conversely, the content of RDP decreased 0.3 to 0.6 percentage units when ABM replaced SBM in the diets. The content of $\mathrm{ADF}, \mathrm{NDF}, \mathrm{NE}_{\mathrm{L}}$, and macrominerals was similar among diets.

\section{Lactational Performance}

The effect of the interaction between percentage and source of CP on DMI was significant during both d 15 to 112 and d 15 to 210 (Table 3). It is noteworthy that this effect was more pronounced during the first $112 \mathrm{~d}$ of lactation (Figure 1). At LCP in the diet, cows fed SBM consumed more DM (expressed as kilograms/day and proportion of BW) than those fed AMB, but this effect was significant only during d 15 to $112(+1.5 \mathrm{~kg} / \mathrm{d}$ and 0.27 percentage units). When dietary $\mathrm{CP}$ increased from LCP to MCP, DMI was numerically higher for cows fed AMB than for those fed SBM. In contrast, with HCP diets SBM resulted in higher DMI than AMB during d 15 to $112(+2.1 \mathrm{~kg} / \mathrm{d}$ and 0.39 percentage units $)$ and $\mathrm{d}$ 15 to $210(+2.5 \mathrm{~kg} / \mathrm{d}$ and 0.51 percentage units $)$. Grant and Haddad (1998) observed that replacing SBM with a mixture of feather and blood meal to supply $4 \%$ of the dietary DM depressed the intake of DM $(-3.5 \mathrm{~kg} / \mathrm{d})$ by dairy cows when the CP content of the diet increased from 17.5 to $19.5 \%$. In other experiments with lactating cows, the factorial effects of the percentage (from 16.2 to 19.9) and source (SBM and various RUP supplements) of dietary CP on DMI were not significant (Christensen et al., 1993; Cunningham et al., 1996). Nonetheless, results reported here agree with those from a meta-analytic review of 93 studies (Ipharraguerre, 2004) showing that the amount of DM consumed by dairy cows was numerically $(-0.5 \%, P>0.05)$ or significantly $(-1.4 \%, P$ $<0.05$ ) decreased by the replacement of RDP sources with RUP supplements in diets that contained either more than $18 \%$ or less than $15.9 \% \mathrm{CP}$, respectively; this effect, however, was positive $(+0.2 \%)$ but not significant $(P>0.05)$ when dietary CP ranged from 16 to $17.9 \%$.

Across CP sources, feeding the LCP diet decreased DMI by 1.1 and $1.3 \mathrm{~kg} / \mathrm{d}$ from d 15 to 112 compared with the MCP and HCP diets, respectively. Similar decreases in DMI were reported when the CP content of the diet fed to moderate- (Weigel et al., 1997) or high-producing (Broderick, 2003) cows was decreased from about 18 to about $15 \%$. However, this negative response to similar decreases in the input of dietary $\mathrm{CP}$ has not always been observed (Kalscheur et al., 1999; Wu and Satter, 2000). A lack of major changes in DMI of high-producing cows fed diets in which the concentration of CP was decreased from 19 or 18 to about $16 \%$ appears to be a more consis- 

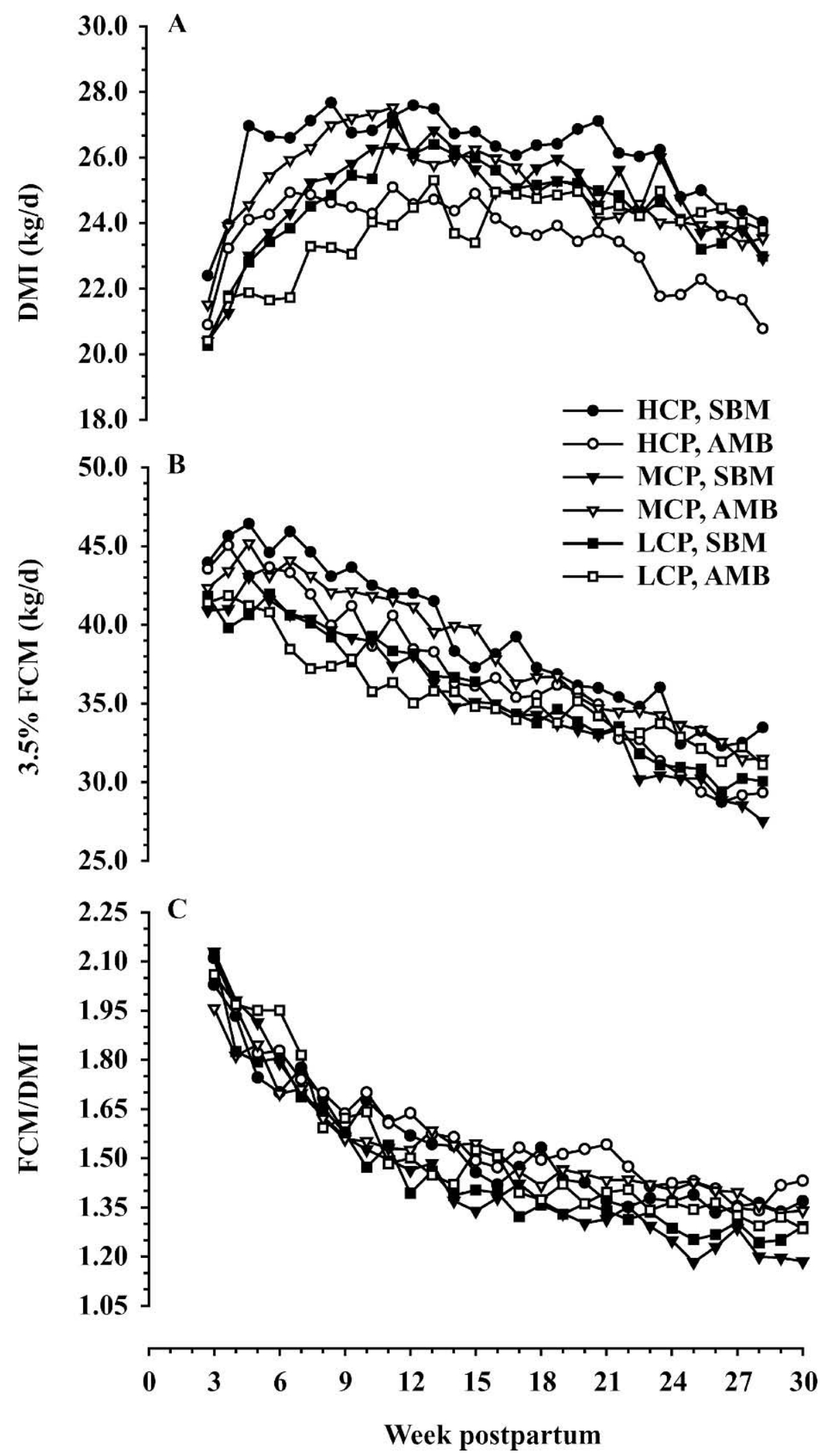

Figure 1. Least square means for DMI (A; SEM = 0.48), production of 3.5\% FCM (B; SEM = 0.81), and ratio FCM/DMI $(\mathrm{C}$; SEM = 0.04) of cows fed diets containing different percentages and sources of CP. The 3 -way interaction $(\mathrm{CP}$ percentage $\times \mathrm{CP}$ source $\times$ week postpartum) was not significant $(P>0.10)$ for all variables. 
tent outcome (Christensen et al., 1993; Cunningham et al., 1996; Komaragiri and Erdman, 1997; Leonardi et al., 2003). In the companion study (Ipharraguerre et al., 2005), the percentage of dietary CP did not alter significantly the ruminal fermentation of organic matter or the amount of microbial $\mathrm{N}$ that passed to the small intestine, suggesting that reduced DMI for the LCP diet was probably independent of a shortage of available $\mathrm{N}$ in the rumen that impaired nutrient digestibility. Even though the molar proportion of propionate was unaffected by the percentage of dietary $\mathrm{CP}$, the amount of starch consumed and fermented in the rumen decreased by 16 and $54 \%$, respectively, as the concentration of $\mathrm{CP}$ increased from LCP to HCP (Ipharraguerre et al., 2005). Therefore, it seems reasonable to speculate that more propionate was produced and absorbed from the rumen of cows fed the LCP diet compared with cows fed higher dietary CP. Increased supply of propionate to the liver might have provided a signal for hypophagia, leading in turn to reduced DMI (Allen, 2000; Oba and Allen, 2003). Another potential explanation is that as CP increased in the diet the concentration of ammonia $\mathrm{N}$ in blood might have increased because of an increase in the ruminal production of ammonia N (Ipharraguerre et al., 2005), resulting in a decline of the glucose-mediated release of insulin by the pancreas (Fernandez et al., 1990) and, consequently, in reduced hunger (Allen, 2000).

Across CP percentages, DMI expressed as kilograms per day and percentage of BW was higher for cows fed SBM than for cows fed AMB during d 15 to $112(+0.9$ $\mathrm{kg} / \mathrm{d}$ and 0.16 percentage units) and during $\mathrm{d} 15$ to 210 when DMI was expressed as percentage of BW $(+0.19$ percentage units; Table 3). In contrast, replacing SBM with the same AMB product (i.e., ProLak) in the diet of dry (Huyler et al., 1999; Underwood, 2003) or lactating (Santos et al., 1999; Underwood, 2003) cows did not affect DMI. It should be noted, however, that the numerical trend reported by Underwood (2003) for DMI of lactating cows $(-1.0 \mathrm{~kg} / \mathrm{d})$ paralleled the significant differences reported here and that the use of the AMB product has depressed feed intake on a number of farms involved in a large field study (Ferguson et al., 2000). Additionally, research summarized elsewhere (Santos et al., 1998; Ipharraguerre and Clark, 2005) indicated that the replacement of SBM with RUP supplements of marine and (or) animal origin has generally depressed DMI. The AMB product contained meals of menhaden fish and hydrolyzed feather (see previous section for details) and the negative impact of these RUP supplements on DMI has been partly attributed to poor palatability of the diet (Mäntysaari et al., 1989; Grant and Haddad, 1998; AbuGhazaleh et al., 2001). Considering that in the companion experiment (Ipharraguerre et al., 2005) the source of supplemental $\mathrm{CP}$ had minor effects on rumen fermen- tation and intestinal supply of nutrients, it is probable that in this experiment reduced palatability might have contributed to decreased DMI of cows fed the AMB diets.

Although the interaction between percentage and source of CP was not significant for milk production (Table 3), the MCP/AMB and HCP/SBM diets resulted in the highest numerical yields of milk during both $\mathrm{d} 15$ to 112 and $d 15$ to 210. As shown in Table 3 and Figure 1 , this interaction was significant for the yield of $3.5 \%$ FCM. During both d 15 to 112 and d 15 to 210 , differences between sources of $\mathrm{CP}$ at LCP in the diet were negligible and not significant; however, AMB resulted in a higher yield of FCM than SBM at MCP $(+3.3$ and $2.9 \mathrm{~kg} / \mathrm{d}$, respectively), whereas the opposite occurred when dietary CP increased to HCP $(-1.6$ and $2.2 \mathrm{~kg} / \mathrm{d}$, respectively). Compared with the MCP and HCP diets, the LCP diet decreased the production of milk during early lactation and the yield of FCM during both d 15 to 112 and d 15 to 210 (Table 3). In contrast, no significant differences for these variables were observed between MCP and HCP. Likewise, the source of CP did not affect the output of milk or FCM. Collectively, these findings indicate that in this experiment the marginal returns in milk and FCM output to the source of supplemental $\mathrm{CP}$ depended on the amount of CP in the diet and that this dependency was particularly marked during the first $112 \mathrm{~d}$ in lactation. When the concentration of dietary CP averaged $16.8 \%$ (i.e., $\mathrm{MCP}$ ), partially replacing SBM with AMB increased yields of milk and FCM. Conversely, the benefits of adding AMB to SBM-based diets were nil when dietary $\mathrm{CP}$ averaged 14.8 (i.e., LCP) or $18.7 \%$ (i.e., $\mathrm{HCP}$ ). Although these significant interactions have not been observed in previous experiments (Christensen et al., 1993; Cunningham et al., 1996; Weigel et al., 1997), they are in agreement with results reported in a summary of 244 treatment comparisons (Ipharraguerre, 2004), indicating that the replacement of RDP sources with RUP supplements significantly $(P<0.05)$ increased milk yield (2.1\%) when diets contained from 16 to $17.9 \%$ $\mathrm{CP}$, whereas below $(\leq 15.9 \%)$ and above $(\geq 18 \%)$ that range the magnitude of this positive effect was less important (1 and $0.6 \%$, respectively) and not significant ( $P$ $>0.05$ ). Similar interactions between the amount and source of dietary CP might have been partly involved in negating an improvement in milk production by dairy cows fed the AMB product in 2 experiments (Santos et al., 1999; Underwood, 2003) and in 16 of 35 herds involved in a field study (Ferguson et al., 2000). As discussed later, alterations in the supply of MP, metabolizable energy (ME), or the interaction of these 2 factors might be at least 3 reasons that could help explain these responses.

During $\mathrm{d} 15$ to 210 , the FCM/DMI ratio tended to be higher for cows fed HCP than for cows fed MCP and 
Table 4. Least square means for BW and BCS of cows fed diets containing different percentages and sources of CP. ${ }^{1}$

\begin{tabular}{|c|c|c|c|c|c|c|c|c|c|c|}
\hline \multirow[b]{3}{*}{ Item } & \multirow{2}{*}{\multicolumn{2}{|c|}{ LCP }} & \multirow{2}{*}{\multicolumn{2}{|c|}{$\mathrm{MCP}$}} & \multirow{2}{*}{\multicolumn{2}{|c|}{$\mathrm{HCP}$}} & \multirow[b]{3}{*}{ SEM } & \multicolumn{3}{|c|}{$\operatorname{Effect}^{2}(P>\mathrm{F})$} \\
\hline & & & & & & & & \multirow[b]{2}{*}{$\mathrm{CP} \%$} & \multirow[b]{2}{*}{ Source } & \multirow{2}{*}{$\begin{array}{l}\mathrm{CP} \% \times \\
\text { source }\end{array}$} \\
\hline & SBM & AMB & SBM & $\mathrm{AMB}$ & SBM & AMB & & & & \\
\hline \multicolumn{11}{|l|}{ BW, kg } \\
\hline d 15 to 112 & $636^{\mathrm{b}}$ & $638^{\mathrm{b}}$ & $644^{\mathrm{a}}$ & $653^{\mathrm{a}}$ & $652^{\mathrm{a}}$ & $653^{\mathrm{a}}$ & 6.7 & 0.05 & $\mathrm{NS}^{3}$ & NS \\
\hline d 15 to 210 & 645 & & 664 & 636 & 649 & 667 & 20.1 & NS & NS & NS \\
\hline Maximum $\operatorname{loss}^{4}$ & $-57.4^{\mathrm{b}}$ & $-72.6^{\mathrm{b}}$ & $-38.3^{\mathrm{a}}$ & $-22.4^{\mathrm{a}}$ & $-34.9^{\mathrm{a}}$ & $-44.9^{\mathrm{a}}$ & 12.79 & 0.02 & NS & NS \\
\hline \multicolumn{11}{|l|}{$\mathrm{BCS}^{5}$} \\
\hline d 15 to 112 & 2.68 & 2.65 & 2.73 & 2.69 & 2.61 & 2.77 & 0.10 & NS & NS & NS \\
\hline d 15 to 210 & 2.81 & 2.79 & 2.89 & 2.81 & 2.66 & 2.93 & 0.10 & NS & NS & 0.03 \\
\hline Maximum $\operatorname{loss}^{4}$ & -0.46 & -0.37 & -0.29 & -0.29 & -0.41 & -0.32 & 0.09 & NS & NS & NS \\
\hline \multicolumn{11}{|c|}{ 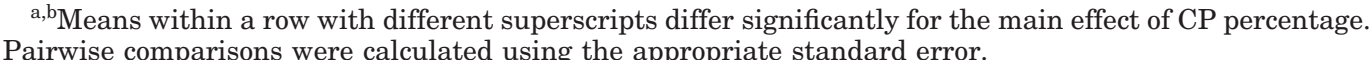 } \\
\hline \multicolumn{11}{|c|}{${ }^{1} \mathrm{AMB}=$ Animal-marine protein blend, $\mathrm{HCP}=$ high $\mathrm{CP}$ diet, $\mathrm{LCP}=$ low $\mathrm{CP}$ diet, $\mathrm{MCP}=$ medium $\mathrm{CP}$ diet } \\
\hline \multicolumn{11}{|c|}{$\begin{array}{l}\mathrm{AMB}=\text { Animal-marine protein blend, } \mathrm{HCP}=\text { high } \mathrm{CP} \text { diet, } \mathrm{LCP}=\text { low } \mathrm{CP} \text { diet, } \mathrm{MCP}=\text { medium } \mathrm{CP} \text { diet, } \\
\mathrm{SBM}=\text { solvent-extracted soybean meal. }\end{array}$} \\
\hline \multicolumn{11}{|c|}{$\begin{array}{l}{ }^{2} \mathrm{CP} \%=\text { Percentage of } \mathrm{CP} \text {, Source }=\text { source of } \mathrm{CP}, \mathrm{CP} \% \times \text { source }=\text { interaction between percentage and } \\
\text { source of CP. The } 2 \text {-way interactions and } 3 \text {-way interaction between factors and week of lactation were not } \\
\text { significant }(P>0.10) \text {. }\end{array}$} \\
\hline \multicolumn{11}{|c|}{${ }^{3}$ Nonsignificant $(P>0.10)$} \\
\hline \multicolumn{11}{|c|}{$\begin{array}{l}{ }^{4} \text { Lowest BW and BCS recorded during the experimental period subtracted from BW and BCS on d } 14 \\
\text { and } \mathrm{d} 7 \text { of the pretreatment period, respectively. }\end{array}$} \\
\hline
\end{tabular}

LCP (Table 3; Figure 1). This trend, however, likely arose from the combination of intermediate FCM yield with numerical lowest DMI for the HCP/AMB diet. In addition, maximum losses of BW and BCS were significantly and numerically largest, respectively, for cows fed the LCP diet (Table 4), suggesting that increased mobilization of body reserves along with reduced DMI and FCM output prevented a decline in the efficiency of feed use by cows fed LCP. Therefore, it seems that the marginal benefits in efficiency of nutrient use for milk production in response to increases in dietary $\mathrm{CP}$ reached a plateau at MCP. Previous research with high-producing cows also showed that reducing the input of dietary CP from $\geq 18 \%$ to within the 16 to $17 \%$ range sustained (Cunningham et al., 1996) or improved (Broderick, 2003) feed efficiency without negatively affecting productivity of cows. The partial replacement of SBM with AMB improved the FCM/DMI ratio (2.5 to $4.4 \%$ ) at all percentages of dietary $\mathrm{CP}$, and this effect was significant during d 15 to 210 (Table 3; Figure 1). Underwood (2003) reported that replacing SBM with AMB to supply $4.75 \%$ of the DM of a diet fed to dairy cows from parturition to $63 \mathrm{~d}$ postpartum, increased the yield of $4 \% \mathrm{FCM}$ per kilogram of DM consumed by about $11 \%$ during d 15 to 63 in lactation. Underwood highlighted, however, that this response was confounded with a larger contribution of labile energy reserves to milk synthesis in cows fed AMB. Based on the evolution of BW, BCS, and FCM/ DMI across the $210 \mathrm{~d}$ of lactation (Figures 1 and 2), different use of body reserves for cows fed either SBM or AMB did not appear to account for the improvement in feed efficiency elicited by AMB in this experiment. Additionally, digestibility of nutrients in the rumen and total digestive tract was not affected by the source of supplemental CP (Ipharraguerre et al., 2005). Consequently, it seems reasonable to speculate that replacing SBM with AMB might have ameliorated imbalances in the profile of essential AA in MP (Ipharraguerre et al., 2005), which contributed to improve the conversion of absorbed nutrients into milk by reducing the energetic cost associated with the required removal of AA supplied in excess. However, changes in the supply of energyyielding substrates resulting from different patterns of ruminal fermentation cannot be ruled out because of the lower ruminal $\mathrm{pH}$ and molar proportion of acetate but higher molar percentages of butyrate and valerate found in the rumen of cows fed SBM compared with cows fed AMB (Ipharraguerre et al., 2005).

An interaction between the percentage and source of $\mathrm{CP}$ was detected for the yield of fat, $\mathrm{CP}(P<0.09)$, and total solids during $d 15$ to 112 and for the same components as well as true protein during d 15 to 210 (Table 5). Compared with AMB, feeding SBM increased significantly or numerically the yield of these milk components at $\mathrm{HCP}$ in the diet, but the opposite happened when dietary $\mathrm{CP}$ was decreased to MCP. Because concentrations in milk of fat, $\mathrm{CP}$, true protein, and total solids were not affected by treatments (Table 5), it appears that the nonsignificant response in milk production was sufficient to account for this interaction. The percentage of lactose in milk tended to be altered by the 2-way interaction and by the concentration of dietary CP dur- 

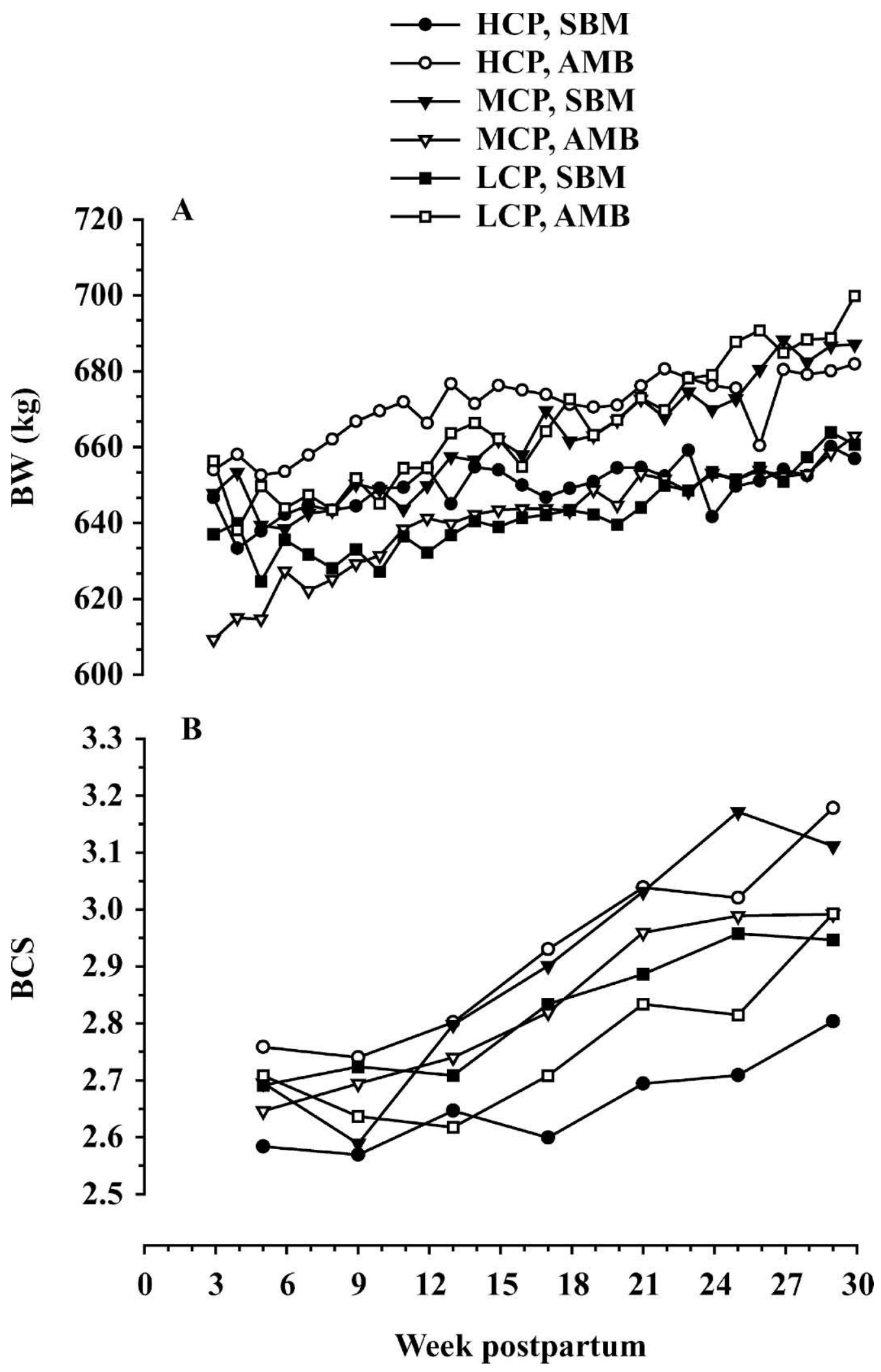

Figure 2. Least square means for BW $(\mathrm{A} ; \mathrm{SEM}=20.1)$ and $\mathrm{BCS}(\mathrm{B} ; \mathrm{SEM}=0.10)$ of cows fed diets containing different percentages and sources of CP. The 3 -way interaction $(\mathrm{CP}$ percentage $\times$ CP source $\times$ week postpartum) was not significant $(P>0.10)$ for all variables. 
Table 5. Least square means for concentration and production of milk components from cows fed diets containing different percentages and sources of $\mathrm{CP} .^{1}$

\begin{tabular}{|c|c|c|c|c|c|c|c|c|c|c|}
\hline \multirow[b]{3}{*}{ Item } & \multirow{2}{*}{\multicolumn{2}{|c|}{ LCP }} & \multirow{2}{*}{\multicolumn{2}{|c|}{$\mathrm{MCP}$}} & \multirow{2}{*}{\multicolumn{2}{|c|}{$\mathrm{HCP}$}} & \multirow[b]{3}{*}{ SEM } & \multicolumn{3}{|c|}{$\operatorname{Effect}^{2}(P>\mathrm{F})$} \\
\hline & & & & & & & & \multirow[b]{2}{*}{$\mathrm{CP} \%$} & \multirow[b]{2}{*}{ Source } & \multirow{2}{*}{$\begin{array}{l}\mathrm{CP} \% \times \\
\text { source }\end{array}$} \\
\hline & $\overline{\mathrm{SBM}}$ & $\mathrm{AMB}$ & $\overline{\mathrm{SBM}}$ & $\mathrm{AMB}$ & $\overline{\mathrm{SBM}}$ & $\mathrm{AMB}$ & & & & \\
\hline \multicolumn{11}{|l|}{ Fat, \% } \\
\hline d 15 to 112 & 3.48 & 3.20 & 3.14 & 3.35 & 3.38 & 3.26 & 0.13 & $\mathrm{NS}^{3}$ & NS & NS \\
\hline d 15 to 210 & 3.53 & 3.30 & 3.20 & 3.37 & 3.45 & 3.31 & 0.14 & NS & NS & NS \\
\hline \multicolumn{11}{|l|}{ Fat, $\mathrm{kg} / \mathrm{d}$} \\
\hline d 15 to 112 & 1.37 & 1.26 & 1.30 & 1.45 & 1.47 & 1.38 & 0.04 & NS & NS & 0.05 \\
\hline d 15 to 210 & 1.25 & 1.20 & 1.18 & 1.31 & 1.36 & 1.25 & 0.04 & NS & NS & 0.04 \\
\hline \multicolumn{11}{|l|}{$\mathrm{CP}, \%$} \\
\hline d 15 to 112 & 3.00 & 3.05 & 3.03 & 3.08 & 3.05 & 3.02 & 0.06 & NS & NS & NS \\
\hline d 15 to 210 & 3.09 & 3.18 & 3.15 & 3.18 & 3.13 & 3.09 & 0.06 & NS & NS & NS \\
\hline \multicolumn{11}{|l|}{$\mathrm{CP}, \mathrm{kg} / \mathrm{d}$} \\
\hline d 15 to 112 & 1.18 & 1.22 & 1.25 & 1.33 & 1.33 & 1.28 & 0.03 & 0.002 & NS & 0.09 \\
\hline d 15 to 210 & 1.11 & 1.18 & 1.17 & 1.23 & 1.23 & 1.18 & 0.03 & 0.07 & NS & 0.03 \\
\hline \multicolumn{11}{|c|}{ True protein, \% } \\
\hline d 15 to 112 & 2.81 & 2.85 & 2.86 & 2.88 & 2.84 & 2.85 & 0.06 & NS & NS & NS \\
\hline d 15 to 210 & 2.90 & 2.98 & 2.97 & 2.98 & 2.92 & 2.91 & 0.06 & NS & NS & NS \\
\hline \multicolumn{11}{|c|}{ True protein, kg/d } \\
\hline d 15 to 112 & $1.10^{\mathrm{b}}$ & $1.14^{\mathrm{b}}$ & $1.18^{\mathrm{a}}$ & $1.24^{\mathrm{a}}$ & $1.25^{\mathrm{a}}$ & $1.20^{\mathrm{a}}$ & 0.03 & 0.001 & NS & NS \\
\hline d 15 to 210 & 1.03 & 1.10 & 1.10 & 1.15 & 1.15 & 1.10 & 0.03 & 0.04 & NS & 0.03 \\
\hline \multicolumn{11}{|l|}{ MUN, mg/dL } \\
\hline d 15 to 112 & $9.02^{\mathrm{c}}$ & $8.20^{c}$ & $11.06^{\mathrm{b}}$ & $11.03^{b}$ & $14.70^{\mathrm{a}}$ & $13.58^{\mathrm{a}}$ & 0.47 & 0.0001 & NS & NS \\
\hline d 15 to 210 & $9.30^{\mathrm{c}}$ & $8.48^{\mathrm{c}}$ & $11.48^{\mathrm{b}}$ & $11.56^{\mathrm{b}}$ & $14.97^{\mathrm{a}}$ & $14.00^{\mathrm{a}}$ & 0.43 & 0.0001 & NS & NS \\
\hline \multicolumn{11}{|l|}{ Lactose, $\%$} \\
\hline d 15 to 112 & 5.04 & 4.94 & 4.93 & 4.98 & 4.94 & 4.86 & 0.04 & 0.06 & NS & 0.06 \\
\hline d 15 to 210 & 4.96 & 4.90 & 4.87 & 4.93 & 4.89 & 4.83 & 0.04 & NS & NS & NS \\
\hline \multicolumn{11}{|l|}{ SCC, $\log 10$} \\
\hline d 15 to 112 & 1.94 & 1.93 & 1.90 & 1.94 & 1.91 & 2.10 & 0.15 & NS & NS & NS \\
\hline d 15 to 210 & 2.02 & 2.08 & 2.04 & 1.97 & 2.04 & 2.20 & 0.11 & NS & NS & NS \\
\hline \multicolumn{11}{|c|}{ Total solids, \% } \\
\hline d 15 to 112 & 12.19 & 11.95 & 11.82 & 12.19 & 12.07 & 11.94 & 0.21 & NS & NS & NS \\
\hline d 15 to 210 & 12.26 & 12.13 & 11.94 & 12.25 & 12.18 & 12.03 & 0.22 & NS & NS & NS \\
\hline \multicolumn{11}{|c|}{ Total solids, kg/d } \\
\hline d 15 to 112 & 4.84 & 4.81 & 4.89 & 5.26 & 5.22 & 5.07 & 0.11 & 0.009 & NS & 0.05 \\
\hline d 15 to 210 & 4.38 & 4.49 & 4.45 & 4.78 & 4.81 & 4.55 & 0.12 & 0.09 & NS & 0.03 \\
\hline
\end{tabular}

${ }^{\mathrm{a}, \mathrm{b}, \mathrm{c}}$ Means within a row with different superscripts differ significantly for the main effect of CP percentage. Pairwise comparisons were calculated using the appropriate standard error.

${ }^{1} \mathrm{AMB}=$ Animal-marine protein blend, $\mathrm{HCP}=$ high $\mathrm{CP}$ diet, $\mathrm{LCP}=$ low $\mathrm{CP}$ diet, $\mathrm{MCP}=$ medium $\mathrm{CP}$ diet, $\mathrm{SBM}=$ solvent-extracted soybean meal.

${ }^{2} \mathrm{CP} \%=$ Percentage of $\mathrm{CP}$, Source $=$ source of $\mathrm{CP}, \mathrm{CP} \% \times$ source $=$ interaction between percentage and source of $\mathrm{CP}$. The 2 -way interactions and 3-way interaction between factors and week of lactation were not significant $(P>0.10)$.

${ }^{3}$ Nonsignificant $(P>0.10)$.

ing d 15 to 112 , but not during d 15 to 210 . Additionally, somatic cell count $(\log 10)$ was unaffected by experimental diets. Similar to results reported here, the replacement of SBM with a mixture of feather and blood meals at 2 concentrations of dietary CP resulted in a significant interaction for the yield of milk, leading to similar trends in the daily outputs of milk fat and protein (Grant and Haddad, 1998). This response, however, has not been observed in a number of studies in which the factorial effects of the amount and source $\mathrm{CP}$ on cow performance were investigated (Christensen et al., 1993; Cunningham et al., 1996; Weigel et al., 1997).

Compared with HCP, decreasing dietary CP to LCP, but not to MCP, depressed the production of $\mathrm{CP}$, true protein, and total solids during both $\mathrm{d} 15$ to 112 and $\mathrm{d}$
15 to 210 (Table 5). These findings support data from experiments with high-producing cows that showed negligible improvements in the output of milk components in response to increased dietary $\mathrm{CP}$ that exceed 16.4 to 17.4\% CP (Cunningham et al., 1996; Wu and Satter, 2000; Broderick, 2003). During d 15 to 210, the secretion of urea in milk (MUN) on average increased $2.53 \mathrm{mg} / \mathrm{dL}$ when dietary CP was increased from LCP to MCP and $3.03 \mathrm{mg} / \mathrm{dL}$ when dietary CP was increased from MCP to HCP. This is consistent with increases in the concentration of ammonia $\mathrm{N}$ in ruminal fluid that were observed at higher concentrations of dietary $\mathrm{CP}$ in the companion experiment (Ipharraguerre et al., 2005) as well as with results obtained in studies in which dietary CP was increased from 15.1 to $18.4 \%$ (Broderick, 2003) 
Table 6. Least square means for estimated energy intake, energy requirements, and energy balance of cows fed diets containing different percentages and sources of CP. ${ }^{1}$

\begin{tabular}{|c|c|c|c|c|c|c|c|c|c|c|}
\hline \multirow[b]{3}{*}{$\mathrm{NE}_{\mathrm{L}}$} & \multirow{2}{*}{\multicolumn{2}{|c|}{$\mathrm{LCP}$}} & \multirow{2}{*}{\multicolumn{2}{|c|}{$\mathrm{MCP}$}} & \multirow{2}{*}{\multicolumn{2}{|c|}{$\mathrm{HCP}$}} & \multirow[b]{3}{*}{ SEM } & \multicolumn{3}{|c|}{$\operatorname{Effect}^{2}(P>\mathrm{F})$} \\
\hline & & & & & & & & \multirow[b]{2}{*}{$\mathrm{CP} \%$} & \multirow[b]{2}{*}{ Source } & \multirow{2}{*}{$\begin{array}{l}\mathrm{CP} \% \times \\
\text { source }\end{array}$} \\
\hline & SBM & $\mathrm{AMB}$ & $\mathrm{SBM}$ & $\mathrm{AMB}$ & $\mathrm{SBM}$ & $\mathrm{AMB}$ & & & & \\
\hline & \multicolumn{6}{|c|}{ (Mcal/d) } & & & & \\
\hline Intake $^{3}$ & 36.9 & 35.4 & 38.0 & 38.5 & 40.4 & 36.2 & 1.01 & $\mathrm{NS}^{4}$ & NS & NS \\
\hline \multicolumn{11}{|l|}{ Requirements } \\
\hline Maintenance ${ }^{5}$ & 10.2 & 10.5 & 10.4 & 10.2 & 10.3 & 10.5 & 0.24 & NS & NS & NS \\
\hline Milk $^{6}$ & 24.5 & 24.8 & 25.1 & 26.0 & 27.3 & 25.0 & 1.03 & NS & NS & 0.08 \\
\hline Total $^{7}$ & 34.7 & 35.3 & 35.6 & 36.1 & 37.6 & 35.5 & 1.18 & NS & NS & NS \\
\hline Balance $^{8}$ & 2.3 & 0.2 & 2.5 & 2.4 & 2.9 & 0.7 & 1.16 & NS & NS & NS \\
\hline
\end{tabular}

${ }^{1}$ Data are least square means for d 15 to 210 of lactation, $\mathrm{AMB}=$ Animal-marine protein blend, $\mathrm{HCP}=$ high CP diet, LCP = low CP diet, MCP = medium CP diet, SBM = solvent-extracted soybean meal.

${ }^{2} \mathrm{CP} \%=$ Percentage of $\mathrm{CP}$, Source $=$ source of $\mathrm{CP}, \mathrm{CP} \% \times$ source $=$ interaction between percentage and source of CP. The 2-way interactions and 3-way interaction between factors and week of lactation were not significant $(P>0.10)$.

${ }^{3}$ Intake $=(\mathrm{DMI}, \mathrm{kg} / \mathrm{d}) \times\left(\mathrm{NE}_{\mathrm{L}} / \mathrm{kg}\right.$ of $\left.\mathrm{DMI}\right)$ where $\mathrm{NE}_{\mathrm{L}}$ was calculated as described in Table 1.

${ }^{4}$ Nonsignificant $(P>0.10)$.

${ }^{5}$ Maintenance $=0.080 \mathrm{Mcal} / \mathrm{kg} \mathrm{BW}^{0.75}(\mathrm{NRC}, 2001)$.

${ }^{6}$ Milk $=(0.0929 \times$ Fat $\%+0.0547 \times \mathrm{CP} \%+0.192) \times($ milk yield, $\mathrm{kg} / \mathrm{d})(\mathrm{NRC}, 2001)$.

${ }^{7}$ Total $=$ Maintenance + milk.

${ }^{8}$ Balance $=$ Intake - total requirements.

or from 16.1 to $18.9 \%$ (Leonardi et al., 2003). Across percentages of dietary $\mathrm{CP}$, the impact of the source of $\mathrm{CP}$ on the content and yield of milk components was not significant. Likewise, other experiments designed to evaluate the effects of replacing SBM with the AMB product did not find changes in milk composition (Santos et al., 1999; Underwood, 2003); although in one of these reports (Underwood, 2003) feeding AMB increased milk fat output during early lactation, whereas in the other trial (Santos et al., 1999) milk protein production was increased during midlactation. In both studies, these positive responses were associated with numerical increases in milk yield, which also occurred in this experiment when AMB replaced SBM at LCP and MCP. With the exception of fish meal, the replacement of SBM with RUP supplements of plant and (or) animal origin has frequently failed to improve the secretion of milk components, particularly of protein (Santos et al., 1998; Ipharraguerre and Clark, 2005).

An explanation for the described interactions might be that at HCP in the diet, the supply of MP exceeded the requirements of the cows and, consequently, SBM resulted in higher yields of FCM and milk components than AMB by increasing the intake of ME. Estimation of energy balance across the $210 \mathrm{~d}$ of lactation based on criteria outlined by the NRC (2001) and estimated dietary concentrations of $\mathrm{NE}_{\mathrm{L}}$ (Table 1 ) showed that feeding SBM at HCP in the diet elicited a nonsignificant increase in $\mathrm{NE}_{\mathrm{L}}$ intake $(+4.2 \mathrm{Mcal} / \mathrm{d})$ that could have accounted for 1.8 times the estimated increase in $\mathrm{NE}_{\mathrm{L}}$ output in milk (+2.3 Mcal/d) when compared with the HCP/AMB diet (Table 6). In the companion study (Ipharraguerre et al., 2005), feeding the HCP diets maximized the intestinal supply of nonammonia $\mathrm{N}$ and nonammonia nonmicrobial $\mathrm{N}$ independently of the source of supplemental CP, which supports further the suggestion that the supply of MP might not have been a limiting factor for the production of milk and milk components when HCP diets were fed. When SBM was partially replaced with $\mathrm{AMB}$ in the MCP diet, the estimated intake of $\mathrm{NE}_{\mathrm{L}}$ (Table 6), and the ruminal digestibilities of $\mathrm{OM}$ and carbohydrates as well as the postruminal supply of $\mathrm{N}$ fractions remained unaffected (Ipharraguerre et al., 2005). Therefore, differences in the outputs of FCM and milk components between SBM and AMB at MCP in the diet might have been related to an attenuation of the imbalance in the profile of EAA in total AA delivered to the small intestine of cows fed the MCP/AMB diet. When cows were fed the LCP diets, however, the quantity of MP supplied to the cows, rather than its AA profile, and (or) the intake of ME might have been less than the requirements of the cows, explaining the lack of effect of the source of supplemental CP on the production of FCM and milk components.

In a literature review of 127 treatment comparisons, Santos et al. (1998) indicated that the productive response of dairy cows to RUP could be influenced by the amount of milk produced. Stratifying and analyzing data according to milk yield ( $<$ or $\geq 40 \mathrm{~kg} / \mathrm{d}$ ) during d 15 to 112 showed that high-producing cows produced more 
Table 7. Least square means for performance of high and low producing cows ${ }^{1}$ fed diets containing different percentages and sources of $\mathrm{CP}^{2}$

\begin{tabular}{|c|c|c|c|c|c|c|c|c|c|c|c|}
\hline \multirow[b]{2}{*}{ Item } & \multicolumn{2}{|c|}{ LCP } & \multicolumn{2}{|c|}{$\mathrm{MCP}$} & \multicolumn{2}{|c|}{$\mathrm{HCP}$} & \multirow[b]{2}{*}{ SEM } & \multirow[b]{2}{*}{ Group } & \multicolumn{2}{|c|}{ Effect $^{3}(P>\mathrm{F})$} & \multirow{2}{*}{$\begin{array}{l}\text { Group } \times \\
\text { CP } \% \times \\
\text { source }\end{array}$} \\
\hline & SBM & $\mathrm{AMB}$ & SBM & $\mathrm{AMB}$ & $\mathrm{SBM}$ & $\mathrm{AMB}$ & & & $\mathrm{CP} \%$ & Source & \\
\hline \multicolumn{12}{|l|}{ Number of cows } \\
\hline High producing cows & 4 & 3 & 4 & 5 & 8 & 5 & & & & & \\
\hline Low producing cows & 5 & 7 & 5 & 5 & 2 & 5 & & & & & \\
\hline \multicolumn{12}{|l|}{ DMI, $\mathrm{kg} / \mathrm{d}$} \\
\hline \multicolumn{12}{|l|}{ Milk, kg/d } \\
\hline High producing cows & 42.3 & 41.5 & 45.8 & 44.7 & 44.7 & 45.4 & 1.8 & 0.0001 & NS & NS & NS \\
\hline \multirow{2}{*}{\multicolumn{12}{|c|}{$3.5 \% \mathrm{FCM},{ }^{5} \mathrm{~kg} / \mathrm{d}$}} \\
\hline & & & & & & & & & & & \\
\hline High producing cows & 40.5 & 39.5 & 41.7 & 43.1 & 44.0 & 42.7 & 1.8 & 0.002 & NS & NS & NS \\
\hline Low producing cows & 38.0 & 37.1 & 37.3 & 40.5 & 38.9 & 38.8 & & & & & \\
\hline \multicolumn{12}{|l|}{ FCM/DMI } \\
\hline \multicolumn{12}{|l|}{ Maximum BW loss, ${ }^{6} \mathrm{~kg}$} \\
\hline High producing cows & -63.0 & -75.3 & -73.8 & -76.4 & -58.2 & -52.5 & 20.6 & NS & NS & NS & NS \\
\hline Low producing cows & -65.0 & -71.1 & -48.7 & -44.3 & -67.5 & -69.5 & & & & & \\
\hline
\end{tabular}

${ }^{1}$ High producing cows $\geq 40 \mathrm{~kg}$ of milk/d (mean $\left.=45.6\right)$, low producing cows $<40 \mathrm{~kg}$ of milk/d (mean $\left.=37.9\right)$.

${ }^{2}$ Data from d 15 to 112 of lactation, $\mathrm{AMB}=$ Animal-marine protein blend, HCP = high CP diet, LCP = low CP diet, MCP = medium CP diet, $\mathrm{SBM}=$ solvent-extracted soybean meal.

${ }^{3}$ Group = high vs. low producing cows, CP\% $=$ percentage of $\mathrm{CP}$, Source $=$ source of CP.

${ }^{4} \mathrm{NS}=$ Nonsignificant $(P>0.10)$.

${ }^{5} 3.5 \% \mathrm{FCM}=0.4324(\mathrm{~kg}$ of milk $)+16.216(\mathrm{~kg}$ of fat $)$.

${ }^{6}$ Lowest BW and BCS recorded during the experimental period subtracted from BW and BCS on d 14 and d 7 of the pretreatment period, respectively.

milk $(+4.9 \mathrm{~kg} / \mathrm{d})$ and $\mathrm{FCM}(+3.5 \mathrm{~kg} / \mathrm{d})$, but consumed similar amounts of feed $(+0.8 \mathrm{~kg} / \mathrm{d})$, than lower producing cows, and that this response was largely mediated by an increase in the efficiency of nutrient use for milk synthesis (i.e., FCM/DMI; Table 7). Although maximum losses of BW were not significantly different between groups, high-producing cows tended to have lower BW than the other cows. These findings are consistent with data indicating that cows of superior genetic potential are capable of supporting greater lactogenic drive by using nutrients more efficiently rather than increasing their consumption (Veerkamp et al., 1995). With the exception of BW, none of the described responses was modulated by the interaction between level of production and the percentage and (or) source of CP. Likewise, the fat and urea content of milk and the yield of milk fat were not affected by the interaction between these factors (Table 8). Westwood et al. (2000) also found that the yield of milk and DMI of cows of low and high genetic merit were not affected differently by the RUP content of the diet (7.7 and 5.0\% of the dietary DM). Conversely, the percentage of true protein in milk of high-producing cows increased when they were fed AMB compared with
$\mathrm{SBM}$ at LCP and MCP in the diet. This response, however, was not observed for the HCP diets or for the lowproducing group. Additionally, reducing dietary $\mathrm{CP}$ to LCP limited the output of true protein but only by the group of high-producing cows. These results suggest that high-producing cows largely accounted for the effects of the percentage and source of dietary $\mathrm{CP}$ on milk protein output discussed earlier in this report. Nonetheless, the number of cows used in this study limited the power with which interactions between groups and dietary factors could be detected.

\section{Nitrogen Use}

Across the $210 \mathrm{~d}$ of lactation, the intake of $\mathrm{N}$ tended to parallel the significant interaction found for DMI (Table 9). That is, SBM resulted in higher $\mathrm{N}$ intake than AMB at HCP in the diet, but this trend was larger for AMB at MCP and not evident at LCP. The percentage of CP, but not the source, profoundly influenced the intake and use of $\mathrm{N}$. Increasing dietary $\mathrm{CP}$ from LCP to HCP increased the amount of $\mathrm{N}$ consumed $(+184 \mathrm{~g} / \mathrm{d})$ and estimated to be excreted in urine $(+93 \mathrm{~g} / \mathrm{d})$ and feces 
Table 8. Least square means for concentration and production of milk components of high and low producing cows ${ }^{1}$ fed diets containing different percentages and sources of $\mathrm{CP} .^{2}$

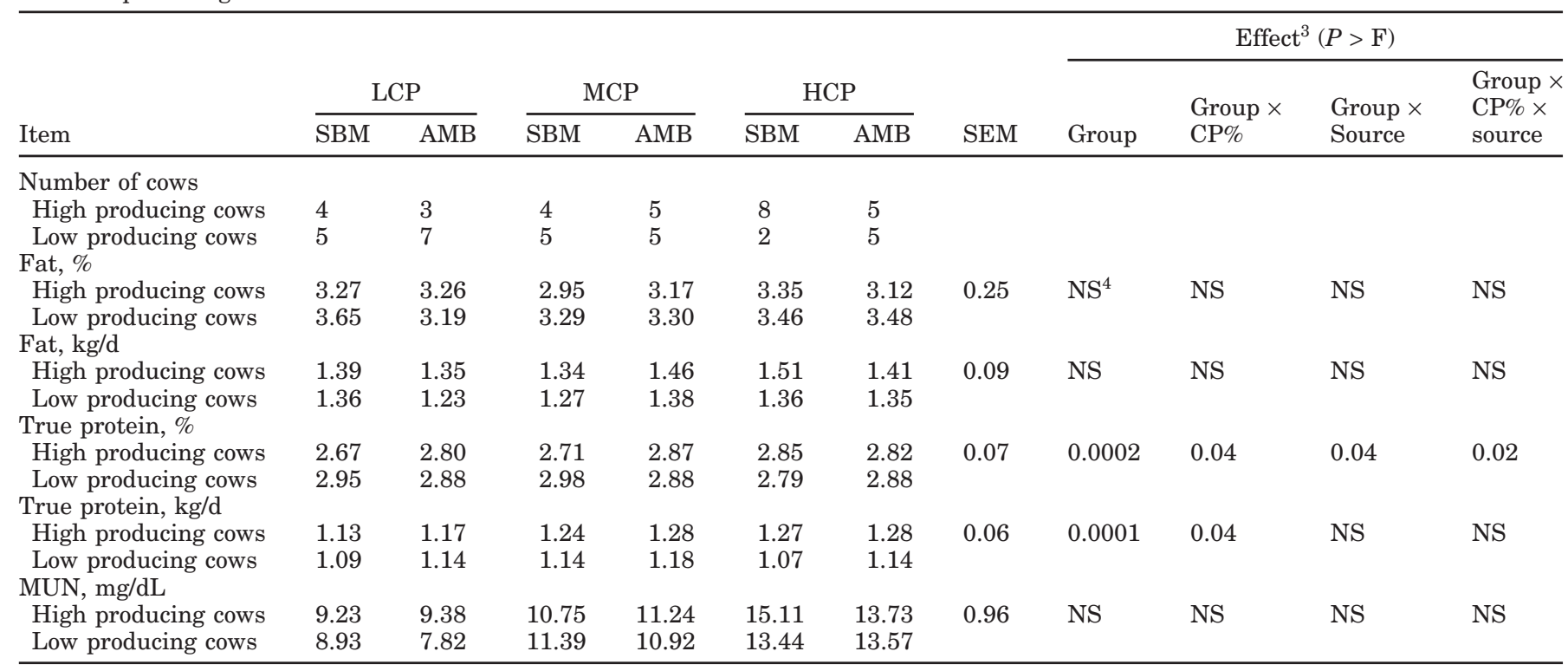

${ }^{1}$ High producing cows $\geq 40 \mathrm{~kg}$ of milk/d (mean $=45.6$ ), low producing cows $<40 \mathrm{~kg}$ of milk/d $(\mathrm{mean}=37.9)$.

${ }^{2}$ Data are least square means for d 15 to 112 of lactation, AMB = Animal-marine protein blend, HCP = high CP diet, LCP = low CP diet, $\mathrm{MCP}=$ medium $\mathrm{CP}$ diet, $\mathrm{SBM}=$ solvent-extracted soybean meal.

${ }^{3}$ Group $=$ high vs. low producing cows, $\mathrm{CP} \%=$ percentage of $\mathrm{CP}$, Source $=$ source of $\mathrm{CP}$.

${ }^{4} \mathrm{NS}=$ Nonsignificant $(P>0.10)$.

$(+78 \mathrm{~g} / \mathrm{d})$ without altering significantly the amount secreted in milk $(+13 \mathrm{~g} / \mathrm{d})$. Differences for the estimated excretion of fecal $\mathrm{N}$ between MCP and HCP, however, were not significant. The gross efficiency of conversion of feed $\mathrm{N}$ into milk $\mathrm{N}$ decreased on average from 32 to $25 \%$ as the concentration of $\mathrm{CP}$ in the diet increased

Table 9. Least square means for $\mathrm{N}$ utilization by cows fed diets containing different percentages and sources of CP. ${ }^{1}$

\begin{tabular}{|c|c|c|c|c|c|c|c|c|c|c|}
\hline \multirow[b]{3}{*}{ Item } & \multirow{2}{*}{\multicolumn{2}{|c|}{ LCP }} & \multirow{2}{*}{\multicolumn{2}{|c|}{$\mathrm{MCP}$}} & \multirow{2}{*}{\multicolumn{2}{|c|}{$\mathrm{HCP}$}} & \multirow[b]{3}{*}{ SEM } & \multicolumn{3}{|c|}{ Effect $^{2}(P>\mathrm{F})$} \\
\hline & & & & & & & & \multirow[b]{2}{*}{$\mathrm{CP} \%$} & \multirow[b]{2}{*}{ Source } & \multirow{2}{*}{$\begin{array}{l}\mathrm{CP} \% \times \\
\text { source }\end{array}$} \\
\hline & SBM & AMB & SBM & AMB & SBM & $\mathrm{AMB}$ & & & & \\
\hline $\mathrm{N}$ intake, $\mathrm{g} / \mathrm{d}$ & 570 & 560 & 660 & 689 & 776 & 721 & 26.8 & 0.0001 & $\mathrm{NS}^{3}$ & 0.08 \\
\hline \multicolumn{11}{|l|}{$\mathrm{N}$ output, $\mathrm{g} / \mathrm{d}$} \\
\hline Urine $^{5}$ & $\begin{array}{r}171 \\
156^{\mathrm{c}}\end{array}$ & $\begin{array}{r}184 \\
148^{\mathrm{c}}\end{array}$ & $\begin{array}{r}186 \\
197^{b}\end{array}$ & $\begin{array}{r}190 \\
195^{\mathrm{b}}\end{array}$ & $\begin{array}{r}195 \\
250^{\mathrm{a}}\end{array}$ & $\begin{array}{r}184 \\
241^{\mathrm{a}}\end{array}$ & $\begin{array}{r}6.8 \\
12.3\end{array}$ & NS & NS & NS \\
\hline Feces $^{6}$ & $244^{\mathrm{b}}$ & $229^{b}$ & $277^{\mathrm{a}}$ & $304^{\mathrm{a}}$ & $331^{\mathrm{a}}$ & $\begin{array}{l}241 \\
296^{\mathrm{a}}\end{array}$ & $\begin{array}{l}12.3 \\
22.0\end{array}$ & 0.0001 & NS & NS \\
\hline \multicolumn{11}{|c|}{$\mathrm{N}$ output, $\% \mathrm{~N}$ intake } \\
\hline Milk & $30^{\mathrm{a}}$ & $33^{\mathrm{a}}$ & $29^{b}$ & $28^{\mathrm{b}}$ & $26^{\mathrm{c}}$ & $25^{\mathrm{c}}$ & 1.3 & 0.0001 & NS & 0.09 \\
\hline Urine & $27^{\mathrm{b}}$ & $27^{\mathrm{b}}$ & $30^{\mathrm{b}}$ & $28^{\mathrm{b}}$ & $32^{\mathrm{a}}$ & $33^{\mathrm{a}}$ & 1.8 & 0.004 & NS & NS \\
\hline Feces & 43 & 40 & 41 & 44 & 42 & 41 & 2.0 & NS & NS & NS \\
\hline
\end{tabular}

a,b,c Means within a row with different superscripts differ significantly for the main effect of $\mathrm{CP}$ percentage. Pairwise comparisons were calculated using the appropriate standard error.

${ }^{1}$ Data are least square means for d 15 to 210 of lactation, $\mathrm{AMB}=$ Animal-marine protein blend, $\mathrm{HCP}=$ high $\mathrm{CP}$ diet, $\mathrm{LCP}=$ low $\mathrm{CP}$ diet, $\mathrm{MCP}=$ medium $\mathrm{CP}$ diet, $\mathrm{SBM}=$ solvent-extracted soybean meal.

${ }^{2} \mathrm{CP} \%=$ Percentage of $\mathrm{CP}$, Source $=$ source of $\mathrm{CP}, \mathrm{CP} \% \times$ source $=$ interaction between percentage and source of CP. The 2-way interactions and 3-way interaction between factors and week of lactation were not significant $(P>0.10)$

${ }^{3}$ Nonsignificant $(P>0.10)$.

${ }^{4}$ Calculated as milk CP $(\mathrm{g} / \mathrm{d}) / 6.38$.

${ }^{5}$ Estimated as $0.026 \times \mathrm{BW}(\mathrm{kg}) \times \mathrm{MUN}(\mathrm{mg} / \mathrm{dL})($ Kauffman and St-Pierre, 2001). $\mathrm{N}$.

${ }^{6}$ Estimated as $\mathrm{N}$ intake - (Milk N + Urine N) and assuming no net deposition or mobilization of tissue 
from LCP to HCP. Within the same range of dietary CP, the proportion of $\mathrm{N}$ intake that was estimated to be excreted in urine increased from 27 to $33 \%$, whereas the percentage estimated to be excreted in feces remained constant among treatments and averaged 42. Similar results were obtained when data for $\mathrm{N}$ use were analyzed for d 42 to 49, d 112 to 119, and d 196 to 203 (data not shown). In agreement with these findings, using data from $19 \mathrm{~N}$ balance studies that involved low- to moderate-producing cows, Castillo et al. (2000) estimated that increasing $\mathrm{N}$ intake from 400 to $750 \mathrm{~g} / \mathrm{d}$ markedly enhanced the partition of $\mathrm{N}$ to urine $\left(0.67 \times \mathrm{N}\right.$ intake; $\mathrm{R}^{2}=$ $0.63)$ and marginally improved its secretion in milk (0.14 $\times N$ intake; $R^{2}=0.14$ ). These authors speculated that $N$ partitioning in low- to moderate-producing cows, particularly the output of $\mathrm{N}$ in urine, could be different from that in cows of high genetic merit. Data from this experiment and from other studies (Leonardi et al., 2003; Noftsger and St-Pierre, 2003) with high-producing cows that consumed from 21.7 to $23.6 \mathrm{~kg}$ of DM daily and produced from 41.0 to $45.2 \mathrm{~kg} / \mathrm{d}$ of milk suggest that when $\mathrm{N}$ intake exceeds about $600 \mathrm{~g} / \mathrm{d}(\sim 16.5 \% \mathrm{CP}$ on DM basis), there are negligible increases in milk $\mathrm{N}$ output. In some studies (Wohlt et al., 1991; Wright et al., 1998; Castillo et al., 2001), but not in others (Kröber et al., 2000a; Knowlton et al., 2001; Leonardi et al., 2003), supplementing diets for lactating cows with RUP and (or) rumen-protected AA decreased urinary $\mathrm{N}$ excretion. Conversely, such strategies have frequently failed to improve the gross conversion of feed $\mathrm{N}$ into milk (Wohlt et al., 1991; Kröber et al., 2000a; Castillo et al., 2001; Knowlton et al., 2001; Leonardi et al., 2003), which is consistent with our results.

\section{CONCLUSIONS}

In this experiment, the productive response of dairy cows to the source of supplemental CP depended on the concentration of $\mathrm{CP}$ in the diet. When the percentage of dietary $\mathrm{CP}$ averaged 18.7, supplementing diets with only SBM maximized DMI and the production of milk and milk components. As a result, the marginal returns in the output of milk and milk protein in response to replacing SBM with RUP plus rumen-protected Met (AMB) were nil, suggesting that the supply of nutrients other than MP, most likely ME, limited cow performance. When the percentage of dietary CP averaged 16.8, however, the partial replacement of SBM with RUP plus rumen-protected Met was required to sustain maximum yields of milk and milk components. This suggests that in this case the supply of MP and its AA composition may have limited the productive response of dairy cows. Supplementing diets with different sources of CP and rumen-protected Met was not effective for maintaining cow productivity when the input of dietary $\mathrm{CP}$ was decreased on average to $14.8 \%$, which indicates that the quantity of MP supplied to the cows, rather than its profile of AA, was insufficient for meeting their requirements. Despite these interactions, improvements in the gross efficiency of $\mathrm{N}$ use for milk production were achieved through reductions in the intake of $\mathrm{N}$ independently of the source of CP.

These results suggest that the intake of $\mathrm{N}$ by highproducing dairy cows that consume sufficient energy and other nutrients to meet their requirements can be decreased to about 600 to $650 \mathrm{~g}$ daily if the source of RDP and RUP are properly matched with the source and amount of carbohydrate in the diet. This strategy would sustain optimal cow productivity throughout the entire lactation and improve the gross conversion of feed $\mathrm{N}$ to milk N.

\section{ACKNOWLEDGMENTS}

The authors thank H. J. Baker \& Bros., Inc. (Westport, CT) for providing ProLak and partial financial support to complete the research presented in this report.

\section{REFERENCES}

Abu-Ghazaleh, A. A., D. J. Schingoethe, and A. R. Hippen. 2001. Blood amino acids and milk composition from cows fed soybean meal, fish meal, or both. J. Dairy Sci. 84:1174-1181.

Allen, M. S. 2000. Effects of diet on short-term regulation of feed intake by lactating dairy cattle. J. Dairy Sci. 83:1598-1624.

AOAC. 1990. Official Methods of Analysis. Vol. I, 15th ed. Association of Official Analytical Chemists, Arlington, VA.

Broderick, G. A. 2003. Effects of varying dietary protein and energy levels on the production of lactating dairy cows. J. Dairy Sci. 86:1370-1381.

Council for Agricultural Science and Technology (CAST). 2002. Animal diet modification to decrease the potential for nitrogen and phosphorus pollution. Issue Paper, No 21. Council for Agricultural Science and Technology, Ames, IA.

Castillo, A. R., E. Kebreab, D. E. Beever, J. H. Barbi, J. D. Sutton, H. C. Kirby, and J. France. 2001. The effect of protein supplementation on nitrogen utilization in lactating dairy cows fed grass silage diets. J. Anim. Sci. 79:247-253.

Castillo, A. R., E. Kebreab, D. E. Beever, and J. France. 2000. A review of efficiency of nitrogen utilisation in lactating dairy cows and its relationship with environmental pollution. J. Anim. Feed Sci. 9:1-32.

Christensen, R. A., G. L. Lynch, J. H. Clark, and Y. Yu. 1993. Influence of amount and degradability of protein on production of milk and milk components by lactating Holstein cows. J. Dairy Sci. 76:3490-3496.

Cunningham, K. D., M. J. Cecava, T. R. Johnson, and P. A. Ludden. 1996. Influence of source and amount of dietary protein on milk yield by cows in early lactation. J. Dairy Sci. 79:620-630.

Dinn, N. E., J. A. Shelford, and L. J. Fisher. 1998. Use of the Cornell Net Carbohydrate and Protein System and rumen-protected lysine and methionine to reduce nitrogen excretion from lactating dairy cows. J. Dairy Sci. 81:229-237.

Ferguson, J. D., D. K. Beede, R. D. Shaver, C. E. Polan, J. T. Huber, and P. T. Chandler. 2000. Effects of inclusion of a blended protein product in 35 herds in five regions of the country. J. Dairy Sci. 83:1813-1828. 
Fernandez, J. M., W. J. Croom, Jr., L. P. Tate, Jr., and A. D. Johnson. 1990. Subclinical ammonia toxicity in steers: Effects on hepatic and portal-drained visceral flux of metabolites and regulatory hormones. J. Anim. Sci. 68:1726-1742.

Grant, R. J., and S. G. Haddad. 1998. Effect of a mixture of feather and blood meals on lactational performance of dairy cows. J. Dairy Sci. 81:1358-1363.

Huyler, M. T., R. L. Kincaid, and D. F. Dostal. 1999. Metabolic and yield responses of multiparous Holstein cows to prepartum rumenundegradable protein. J. Dairy Sci. 82:527-536.

Hvelplund, T., and J. Madsen. 1996. Protein utilization in ruminants. Pages 83-93 in Proc. 7th Intl. Symp. Prot. Met. Nutr. Vale de Santarem, Portugal. EAAP, The Netherlands. National Institue of Animal Science, Foulum, Denmark.

Ipharraguerre, I. R. 2004. Nutritional strategies for optimizing nitrogen utilization by dairy cows. Ph.D. Thesis, Univ. of Illinois, Urbana.

Ipharraguerre, I. R., and J. H. Clark. 2005. Impacts of the source and amount of crude protein on the intestinal supply of nitrogen fractions and performance of dairy cows. J. Dairy Sci. 88(E. Suppl.):E22-E37.

Ipharraguerre, I. R., J. H. Clark, and D. E. Freeman. 2005. Varying protein and starch in the diet of dairy cows. I. Effects on ruminal fermentation and intestinal supply of nutrients. J. Dairy Sci. 88:2537-2555.

Jonker, J. S., R. A. Kohn, and J. High. 2002. Dairy herd management practices that impact nitrogen utilization efficiency. J. Dairy Sci. 85:1218-1226.

Kalscheur, K. F., J. H. Vandersall, R. A. Erdman, R. A. Kohn, and E. Russek-Cohen. 1999. Effects of dietary crude protein concentration and degradability on milk production responses of early, mid, and late lactation dairy cows. J. Dairy Sci. 82:545-554.

Kauffman, A. J., and N. R. St-Pierre. 2001. The relationship of milk urea nitrogen to urine nitrogen excretion in Holstein and Jersey cows. J. Dairy Sci. 84:2284-2294.

Klausner, S. D. 1993. Mass nutrient balances on dairy farms. Pages 126-129 in Proc. Cornell Nutr. Conf. Feed Manuf., Syracuse, NY. Cornell Univ., Ithaca, NY.

Knowlton, K. F., J. H. Herbein, M. A. Meister-Weisbarth, and W. A. Wark. 2001. Nitrogen and phosphorus partitioning in lactating Holstein cows fed different sources of dietary protein and phosphorus. J. Dairy Sci. 84:1210-1217.

Kohn, R. A., Z. Dou, J. D. Ferguson, and R. C. Boston. 1997. A sensitivity analysis of nitrogen losses from dairy farms. J. Environ. Manage. 50:417-428.

Komaragiri, M. V., and R. A. Erdman. 1997. Factors affecting body tissue mobilization in early lactation dairy cows. 1. Effect of dietary protein on mobilization of body fat and protein. J. Dairy Sci. 80:929-937.

Kröber, T. F., M. Kreuzer, M. Senn, W. Langhams, and F. Sutter. 2000a. Lactational and metabolic effects in cows of lysine and methionine added to a ration deficient according to the INRA method. Arch. Anim. Nutr. 53:375-394.

Kröber, T. F., D. R. Külling, H. Menzi, F. Sutter, and M. Kreuzer. 2000b. Quantitative effects of feed protein reduction and methionine on nitrogen use by cows and nitrogen emissions from slurry. J. Dairy Sci. 83:2941-2951.

Leonardi, C., M. Stevenson, and L. E. Armentano. 2003. Effect of two levels of crude protein and methionine supplementation on performance of dairy cows. J. Dairy Sci. 86:4033-4042.

Littell, R. C., G. A. Milliken, W. W. Stroup, and R. D. Wolfinger. 1996. SAS system for mixed models. SAS Institute Inc., Cary, NC.
Lobley, G. E. 2002. Protein turnover-What does it mean for animal production? Pages 1-15 in Proc. Symp. Amino Acids: Meat, Milk, and More. H. Lapierre and D. R. Ouellet, ed. Quebec, Canada. Can. Soc. Anim. Sci.

Mäntysaari, P. E., C. J. Sniffen, T. V. Muscato, J. M. Lynch, and D. M. Barbano. 1989. Performance of cows in early lactation fed isonitrogenous diets containing soybean meal or animal by-product meals. J. Dairy Sci. 72:2958-2967.

National Research Council. 2001. Nutrient Requirements of Dairy Cattle. 7th rev. ed. Natl. Acad. Sci., Washington, DC.

Noftsger, S., and N. R. St-Pierre. 2003. Supplementation of methionine and selection of highly digestible rumen undegradable protein to improve nitrogen efficiency for milk production. J. Dairy Sci. 86:958-969.

Oba, M., and M. S. Allen. 2003. Intraruminal infusion of propionate alters feeding behavior and decreases energy intake of lactating dairy cows. J. Nutr. 133:1094-1099.

Rotz, C. A., L. D. Satter, D. R. Mertens, and R. E. Muck. 1999. Feeding strategy, nitrogen cycling, and profitability of dairy farms. J. Dairy Sci. 82:2841-2855.

Santos, F. A. P., J. E. P. Santos, C. B. Theurer, and J. T. Huber. 1998. Effects of rumen-undegradable protein on dairy cow performance: A 12-year literature review. J. Dairy Sci. 81:3182-3213.

Santos, J. E. P., J. T. Huber, C. B. Theurer, L. G. Nussio, M. Tarazon, and F. A. P. Santos. 1999. Response of lactating dairy cows to steam-flaked sorghum, steam-flaked corn, or steam-rolled corn and protein sources of differing degradability. J. Dairy Sci. 82:728-737.

SAS Institute. 2000. SAS System for Windows. Release 8.1 (TS1 MO). SAS Institute, Inc., Cary, NC.

Spears, R. A., R. A. Kohn, and A. J. Young. 2003. Whole-farm nitrogen balance on Western dairy farms. J. Dairy Sci. 86:4178-4186.

St-Pierre, N. R., and C. S. Thraen. 1999. Animal grouping strategies, sources of variation, and economic factors affecting nutrient balance on dairy farms. J. Dairy Sci. 82(Suppl. 2):72-82.

Underwood, J. P. 2003. Protein nutrition of dairy cows during the transition period. Ph.D. Thesis. Univ. of Illinois, Urbana.

Van Soest, P. J., J. B. Robertson, and B. A. Lewis. 1991. Methods for dietary fiber, neutral detergent fiber, and nonstarch polysaccharides in relation to animal nutrition. J. Dairy Sci. 74:3583-3597.

Veerkamp, R. F., G. Simm, and J. D. Oldham. 1995. Genotype by environment interactions: Experience from Langhill. Pages 59-65 in Breeding and Feeding the High Genetic Merit Dairy Cow. Br. Soc. Anim. Sci. Occ. Publ. No. 19. Br. Soc. Anim. Sci., Penicuik, UK.

Weigel, D. J., J. P. Elliott, and J. H. Clark. 1997. Effects of amount and ruminal degradability of protein on nutrient digestibility and production by cows fed tallow. J. Dairy Sci. 80:1150-1159.

Westwood, C. T., I. J. Lean, J. K. Garvin, and P. C. Wynn. 2000. Effects of genetic merit and varying dietary protein degradability on lactating dairy cows. J. Dairy Sci. 83:2926-2940.

Wildman, E. E., G. M. Jones, P. E. Wagner, R. L. Boman, H. F. Troutt, Jr., and T. N. Lesch. 1982. A dairy cow body condition scoring system and its relationship to selected production characteristics. J. Dairy Sci. 65:495-501.

Wohlt, J. E., S. L. Chmiel, P. K. Zajac, L. Backer, D. B. Blethen, and J. L. Evans. 1991. Dry matter intake, milk yield and composition, and nitrogen use in Holstein cows fed soybean, fish, or corn gluten meals. J. Dairy Sci. 74:1609-1622.

Wright, T. C., S. Moscardini, P. H. Luimes, P. Susmel, and B. W. McBride. 1998. Effects of rumen-undegradable protein and feed intake on nitrogen balance and milk protein production in dairy cows. J. Dairy Sci. 81:784-793.

Wu, Z., and L. D. Satter. 2000. Milk production during the complete lactation of dairy cows fed diets containing different amounts of protein. J. Dairy Sci. 83:1042-1051. 